\title{
REVIEW: APLIKASI PENGGUNAAN SENSOR BERBASIS ION DALAM MENINGKATKAN AKURASI PEMBERIAN NUTRISI PADA SISTEM TANAM HIDROPONIK
}

\author{
Jonni Firdaus ${ }^{1, *}$, Furqon ${ }^{2}$ \\ ${ }^{1}$ BPTP Sulawesi Tengah, Badan Litbang Pertanian \\ ${ }^{2}$ Program Studi Teknik Pertanian, Fakultas Pertanian, Universitas Jendral Soedirman \\ *Korespondensi, Email: jonni_firdaus@yahoo.com \\ DOI: https://doi.org/10.20884/1.jaber.2021.2.2.5006 \\ Naskah ini diterima pada 12 September 2021; revisi pada 24 September 2021; \\ disetujui untuk dipublikasikan pada 10 November 2021
}

\begin{abstract}
ABSTRAK
Pemenuhan kebutuhan pangan di dalam perkotaan dapat dilakukan melalui pemanfaatan lahan dan air yang lebih efisien dengan sistem tanam hidroponik. Penggunaan aliran nutrisi tertutup merupakan suatu cara untuk mengurangi biaya dan meminimalkan dampak lingkungan dari sistem hidroponik. Dalam sistem tertutup, sangat penting untuk menentukan konsentrasi nutrisi dalam larutan sisa untuk mengisi kembali larutan nutrisi dengan komposisi hara optimal. Saat ini pengukuran ketersediaan hara di dalam larutan nutrisi berdasarkan konduktifitas listrik (EC) yang memiliki kelemahan karena EC meter hanya dapat menggambarkan konduktifitas listrik dari total ion dan tidak mengukur konsentrasi masing-masing ion secara individu sehingga tidak dapat memantau kebutuhan tanaman secara real-time terhadap masingmasing ion di dalam larutan nutrisi. Untuk mengatasi permasalahan tersebut maka saat ini telah mulai dikembangkan teknologi ion selective electrodes (ISE) yaitu suatu sensor berupa elektroda yang dapat mengukur konsentrasi masing-masing ion di dalam larutan nutrisi hidroponik. Penerapan sensor ISE memberikan nilai akurasi yang tinggi terhadap pengukuran konsentrasi ion di dalam larutan nutrisi, sehingga bila dipadukan dengan mekanisme sistem kontrol yang dapat mengontrol penambahan jumlah ion kedalam larutan nutrisi pada sistem hodroponik secara tertutup sesuai kebutuhan tanaman, maka kesetimbangan jumlah ion pada larutan nutrisi akan tetap terjaga pada level kebutuhan tanaman sehingga tanaman dapat tumbuh dengan baik dan menghasilkan produktivitas optimum. Efisiensi penggunaan unsur hara juga meningkat dan dapat mengurangi pencemaran lingkungan karena sisa drainase nutrisi dapat digunakan kembali.
\end{abstract}

Kata kunci: Hidroponik, larutan nutrisi, ion selective electrodes (ISE), sistem kontrol

\section{PENDAHULUAN}

Tren perkembangan penduduk di perkotaan di dunia menjadi lebih besar dibanding di perdesaan. Hal ini terjadi karena adanya urbanisasi dari perdesaan ke perkotaan akibat daya tarik kota dalam pemenuhan kesejahteraan dan gaya hidup manusia. Menurut FAO, sejak 2009, penduduk perkotaan lebih banyak dari penduduk perdesaan, dan diperkirakan pada tahun 2050 populasi kota akan mencapai $70 \%$ dari populasi dunia yang diperkirakan 9 miliar (Ruiz et al, 2014). Berdasarkan data tersebut perlu dicari alternatif baru berkaitan dengan pemenuhan kebutuhan pangan dan penghematan ketersediaan air diperkotaan. Untuk penghematan biaya trasportasi dan energi, kebutuhan pangan dapat diusahakan bersumber dari dalam itu sendiri dengan sistem pertanian perkotaan melalui pemanfaatan lahan dan air yang lebih efisien. Salah satu sistem pertanian perkotaan adalah hidroponik. 
Hidroponik adalah cara menanam tanaman tanpa menggunakan media tanah, menggunakan aliran air yang mengandung nutrisi mineral. Sistem hidroponik dapat dilakukan di luar ruangan atau di dalam ruangan dalam formasi vertikal, horizontal, dan dapat juga di letakkan pada dinding. Sistem ini dapat menghemat air, energi, ruang, dan biaya. Penghematan air bias mencapai 5-10 kali karena menggunakan sistem aliran nutrisi tertutup, dan dapat menghasilkan pangan hingga 10 kali lebih banyak daripada metode konvensional (Winterborne, 2005 dalam Ruiz et al 2014). Nuutrisi/hara pada sistem hidroponik diberikan dalam bentuk larutan sehingga lebih efisien. Metode ini memiliki banyak keuntungan, termasuk pengurangan masalah hama, pemberian nutrisi ke akar sesuai dengan kebutuhan tanaman secara konstan sehingga produktivitas tanaman menjadi lebih tinggi (Jung, 2014). Sistem hidroponik tidak menggunakan tanah sehingga dapat menurunkan serangan organisme pengganggu tanaman, akibatnya penggunaan pestisida berkurang.

Unsur hara dalam larutan nutrisi terdiri dari makronutrien berupa nitrogen $(\mathrm{N})$, fosfor (P), dan kalium (K) yang sangat penting untuk pertumbuhan tanaman. Nutrisi ini diserap tanaman dalam berbagai bentuk ion, seperti nitrat $\left(\mathrm{NO}_{3}{ }^{-}\right)$, fosfat $\left(\mathrm{H}_{2} \mathrm{PO}_{4}{ }^{-}\right.$atau $\left.\mathrm{HPO}_{4}{ }^{2-}\right)$, kalium $\left(\mathrm{K}^{+}\right)$, kalsium $\left(\mathrm{Ca}^{2+}\right)$, mangnesium $\left(\mathrm{Mg}^{2+}\right)$, dan sulfat $\left(\mathrm{SO}_{4}{ }^{2+}\right)$ yang diserap melalui akar secara difusi. Selain makronutrient ada juga mikronutrient $\left(\mathrm{Fe}^{2+}\right.$, $\mathrm{Mn}^{2+}, \mathrm{BO}_{3}{ }^{3-}, \mathrm{Zn}^{2+}, \mathrm{Cu}^{2+}$ dan $\mathrm{Mo}^{3+}$ ) (Havlin et al., 1999 dalam Kim et al 2013; Ruiz et al 2014).

Penggunaan aliran nutrisi tertutup dengan cara resirkulasi dan penggunaan kembali larutan nutrisi merupakan suatu cara untuk mengurangi biaya dan meminimalkan dampak lingkungan, seperti polusi tanah dan air yang disebabkan oleh larutan nutrisi yang digunakan (Jung et al., 2015; Ruiz et al., 2014). Dalam sistem hidroponik tertutup, penentuan konsentrasi nutrisi dalam larutan sisa sangat penting, agar dapat diketahui jumlah nutrisi yang harus ditambahkan kembali ke dalam larutan nutrisi sehingga komposisi hara larutan optimal sesuai dengan kebutuhan tanaman. Komposisi nutrisi yang tidak seimbang sesuai dengan kebutuhan tanaman dapat menghambat pertumbuhan dan produksi tanaman (Gutierrez et al, 2007 dalam Kim et al, 2013). Pengukuran konsentrasi nutrisi dalam larutan hidroponik secara akurat akan meningkatkan efisiensi penggunaan hara untuk pertumbuhan tanaman karena penambahan kembali unsur hara ke dalam larutan dapat dilakukan dengan komposisi optimal sesuai dengan kebutuhan tanaman (Savvas, 2002 dalam Kim et al, 2017).

Pengontrolan larutan nutrisi hidroponik dengan tepat sangat penting agar tanaman dapat tumbuh dengan sehat dan menghasilkan produksi yang tinggi. Pengontrolan nutrisi juga mengurangi biaya yang terkait dengan pemupukan. Nutrisi larutan dapat dipantau dan dikontrol menggunakan instrumen yang paling umum digunakan yaitu elektrik conductifity (EC) meter, dan yang diukur berupa nilai konduktifitas listrik dari total ion. Dengan informasi ini, dapat ditentukan secara kasar tingkat kebutuhan nutrisi pupuk, tetapi tidak diketahui dengan tepat ketersediaan masing-masing ion makronutrien dan mikronutrien (Ruiz et al, 2014). Konsentrasi larutan dijaga melalui injeksi otomatis larutan nutrisi ke dalam reservoir larutan nutrisi hidroponik secara proporsional berdasarkan penurunan nilai EC larutan akibat serapan hara oleh tanaman (Jung et al, 2019).

Penggunaan EC meter dalam pengukuran ketersediaan hara dalam larutan nutrisi memiliki kelemahan karena EC meter hanya menggambarkan konduktifitas listrik dari total ion dan tidak dapat mengukur konsentarsi per masing-masing ion secara individu sehingga tidak dapat memantau secara real-time kebutuhan tanaman terhadap masing- 
masing ion di dalam larutan nutrisi (Cloutier et al., 1997 dalam Kim et al 2013). Walaupun nilai EC telah memenuhi kebutuhan standar tanaman namun keseimbangan ion-ion di dalam larutan nutrisi belum tentu sesuai dengan kebutuhan tanaman. Akibatnya terjadi kekurangan terhadap ion tertentu, sementara disisi lain terjadi kelebihan ion yang menjadi polusi pada larutan air (Jung et al, 2015). Untuk mengatasi permasalahan tersebut maka saat ini telah mulai dikembangkan teknologi ion selective electrodes (ISE) yaitu suatu sensor berupa elektroda yang dapat mengukur kensentrasi masing-masing ion di dalam larutan nutrisi hidroponik.

\section{Teknologi Sensor Ion Selective Electrodes (ISE)}

Teknologi ion selective electrodes (ISE) yaitu suatu sensor berupa elektroda yang dapat mengukur konsentrasi masing-masing ion di dalam larutan nutrisi hidroponik. Komponen utama pada sensor ISE adalah membran yang dapat merespon secara selektif terhadap suatu zat dengan adanya ion dalam suatu larutan. Dari beberapa penelitian ada beberapa ion penting dalam larutan hidroponik yang telah dapat diukur secara individual menggunakan ISE diantaranya adalah nitrat $\left(\mathrm{NO}_{3}^{-}\right)$, kalium $\left(\mathrm{K}^{+}\right)$, Kalsium $\left(\mathrm{Ca}^{2+}\right)$, dan magnesium $\left(\mathrm{Mg}^{2+}\right)$.

Keunggulan penggunaan ISE adalah mudah dalam penggunaannya, pengukuran bersifat langsung dan real time, memiliki sensivitas dalam rentang konsentrasi yang luas, biaya operasional yang rendah serta bersifat portable.

Ada beberapa kelemahan dari penerapan ISE yaitu terdapat interverensi kimia dari ion-ion lain di dalam larutan karena sebenarnya ISE tidak benar-benar mengukur secara spesifik ion tertentu namun ISE juga merespon sedikit banyak interferensi ion lain. Namun masalah interferensi ini dapat diminimalisasi dengan penerapan data prosesing seperti penerapan model kalibrasi multivariate yang dapat mendeterminasi konsentrasi ion secara individu di dalam suatu larutan. (Foster et al 1991 dalam Kim et al, 2013). Kelemahan lain adalah adanya gangguan kotoran dan biofilm yang disebabkan oleh material organik di dalam larutan, akumulasi dari kotoran dan biofilm dapat mengurangi akurasi pengukuran. Hal ini dapat diatasi dengan pencucian dan pengkalibrasian ISE secara berkala yang dilakukan dengan bantuan sistem kontrol untuk menjaga kebersihan ISE.

Aplikasi penggunaan ISE yang dikontrol oleh komputer ataupun mikrokontroler pada sistem tanam hidroponik dapat dilihat pada Gambar 1. Pada Gambar 1 dapat dilihat bahwa pemberian nutrisi untuk masing-masing ion ke dalam reservoir larutan melalui pengontrolan pompa atau katub seleniod oleh komputer/mikrokontroler yang dosis kebutuhan ionnya dihitung menggunakan formula/algoritma tertentu berdasarkan masukan informasi jumlah ion di dalam reservoir larutan dari sensor ISE. Setiap ion memiliki larutan standar masing-masing pada wadah yang berbeda. Jumlah wadah dan sensor ISE yang dibutuhkan berdasarkan seberapa banyak ion-ion yang akan dikontrol. 


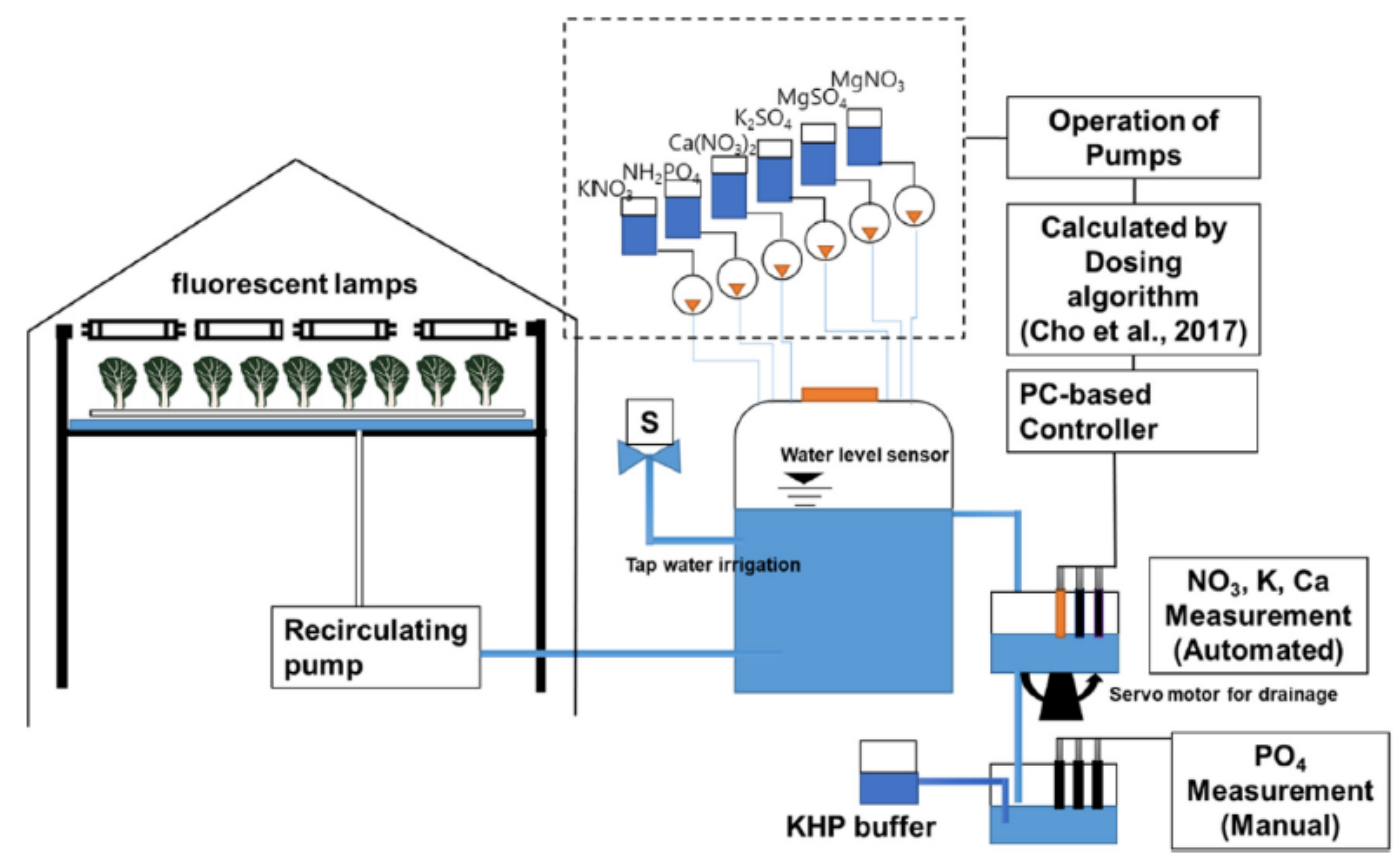

Gambar 1. Skema pengontrolan nutrisi berdasarkan kebutuhan ion pada sistem tanam hidroponik (Jung et al., 2019)

\section{Jenis Dan Desain Sensor Ion Selective Electrodes (ISE)}

Ada beberapa sensor ISE yang telah dijual secara komersil yang dapat mengukur ion secara tunggal seperti $\mathrm{NO}_{3}^{-}$ISE (CNT ISE C62, NT Sensor), $\mathrm{K}^{+}$ISE (CNT ISE C39, NT Sensor), Mg, Cu, namun terdapat juga sensor ISE yang dapat mendeteksi 4 ion sekaligus seperti $\mathrm{NO}_{3}^{-}, \mathrm{K}^{+}, \mathrm{Ca}^{2+}$ dan $\mathrm{Cl}^{-}$(CNT ISE M41, NT Sensor) (Ruiz et al, 2014). Salah satu contoh sensor ISE untuk ion nitrat dapat dilihat pada Gambar 2.

Untuk membuat sensor ISE dibutuhkan sebuah membran ion selektif berbasis PVC. Campuran kimia untuk masing-masing membran ISE dapat dilihat pada Tabel 1. Membran berbentuk disk berdiameter $2.5 \mathrm{~mm}$ dipasang diujung sebuah probe plastik dengan panjang $44 \mathrm{~mm}$ menggunakan larutan tetrahidrofuran (THF). Setiap ISE diisi dengan larutan internal berupa $0.01 \mathrm{M} \mathrm{NaNO}_{3}+0.01 \mathrm{NaCl}$ untuk ISE $\mathrm{NO}_{3}, 0.01 \mathrm{M} \mathrm{KCl}$ untuk ISE K, 0.01M $\mathrm{CaCl}_{2}$ untuk ISE Ca dan 0.01M $\mathrm{MgCl}_{2}$ untuk ISE Mg. Sementara itu untuk elektroda inner referens digunakan elektroda $\mathrm{Ag} / \mathrm{AgCl}$ dengan membalut kabel silver (99\%) berdiameter $1 \mathrm{~mm}$ dengan tinta $\mathrm{Ag} / \mathrm{Ag} \mathrm{Cl}$. Sebuah glass electrode ganda digunakan sebagai elektroda referensi (Kim et al, 2013) 


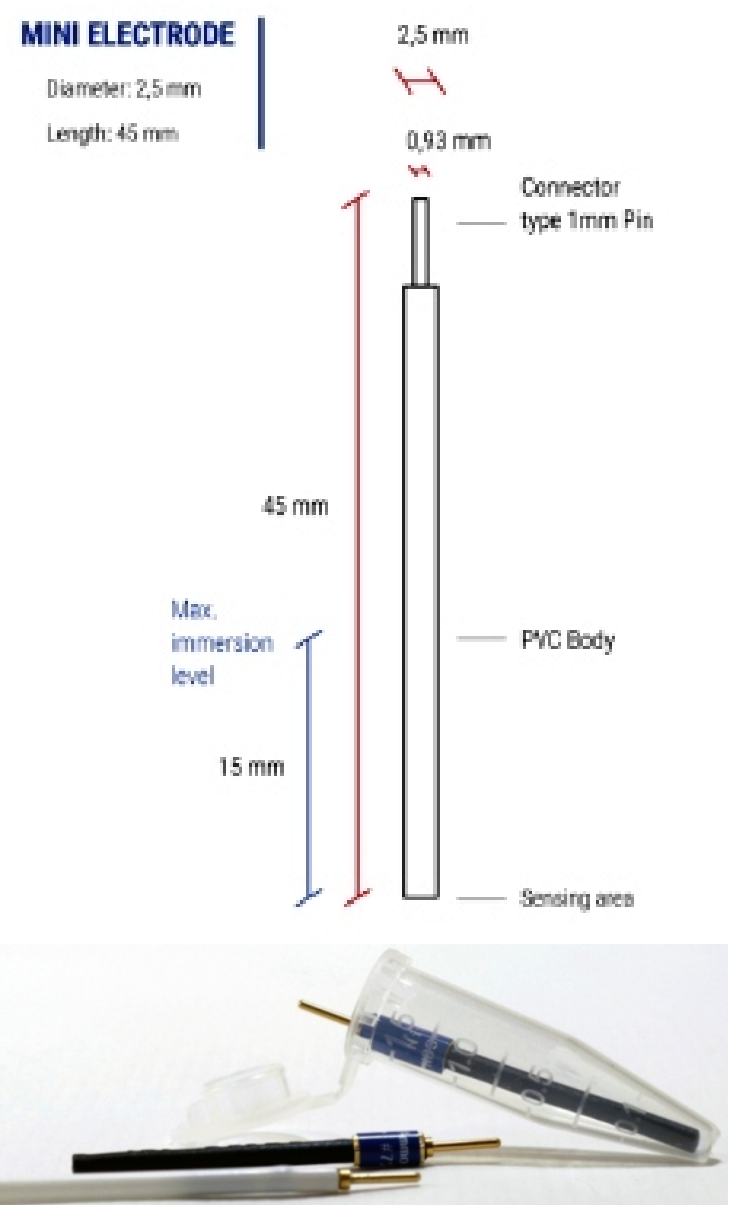

Gambar 2. Sensor ISE Nitrat komersial (CNT ISE M062, NT Sensor)

Tabel 1. Komposi kimia dari membran ISE untuk ion $\mathrm{NO}_{3}, \mathrm{~K}$, Ca, dan Mg

\begin{tabular}{|c|c|c|c|c|c|}
\hline \multirow{2}{*}{$\begin{array}{l}\text { Ion } \\
\text { Target }\end{array}$} & \multicolumn{2}{|l|}{ Elemen Sensor } & \multicolumn{2}{|l|}{ Palstizier } & \multirow{2}{*}{$\begin{array}{c}\text { PVC } \\
\text { (wt } \\
\%)\end{array}$} \\
\hline & Komponen & $\begin{array}{l}\mathrm{wt} \\
\%\end{array}$ & Komponen & $\begin{array}{l}\mathrm{wt} \\
\%\end{array}$ & \\
\hline $\mathrm{NO}_{3}^{-}$ & $\begin{array}{l}\text { TDDA: Tetradodecylammonium } \\
\text { nitrate }\end{array}$ & 15 & $\begin{array}{l}\text { NPOE: 2-nitrophenyl } \\
\text { octylether }\end{array}$ & 40 & 45 \\
\hline \multirow[t]{2}{*}{$\mathrm{K}^{+}$} & Valinomycin & 2,0 & DOS: bis(2-etyhexyl & 64,7 & 32,8 \\
\hline & $\begin{array}{l}\text { KTpCIPB : Potassium tetrakis (4- } \\
\text { chloropheny)borat }\end{array}$ & 0,5 & & & \\
\hline \multirow[t]{2}{*}{$\mathrm{Ca}^{2+}$} & Calcium ionophore II & 1,0 & NPOE & 65,6 & 32,8 \\
\hline & $\begin{array}{l}\text { KTpCIPB : Potassium tetrakis (4- } \\
\text { chloropheny)borat }\end{array}$ & 0,6 & & & \\
\hline \multirow[t]{4}{*}{$\mathrm{Mg}^{2+}$} & Magnesiun Ionophre I & 1,4 & NPOE & 64,5 & 33,1 \\
\hline & $\begin{array}{l}\text { KTpCIPB : Potassium tetrakis (4- } \\
\text { chloropheny)borat }\end{array}$ & 1,0 & & & \\
\hline & Magnesiun Ionophre III & 1,0 & Chloroparafin & 65,5 & 32,9 \\
\hline & $\begin{array}{l}\text { KTpCIPB : Potassium tetrakis (4- } \\
\text { chloropheny)borat }\end{array}$ & 0,6 & & & \\
\hline
\end{tabular}

Sumber : Kiem et al (2013) 
Ada beberapa sensor ISE yang belum tersedia secara komersil di pasaran diantaranya yaitu ISE pospat. Jung et. al. (2019) telah membangun sebuah sensor ISE untuk mengukur ion pospat di dalam larutan nutrisi dengan elekrode berbasis cobalt. Mekanisme mendeteksi pospat dan desain sensor ISE pospat dapat dilihat pada Gambar 3.

(a)

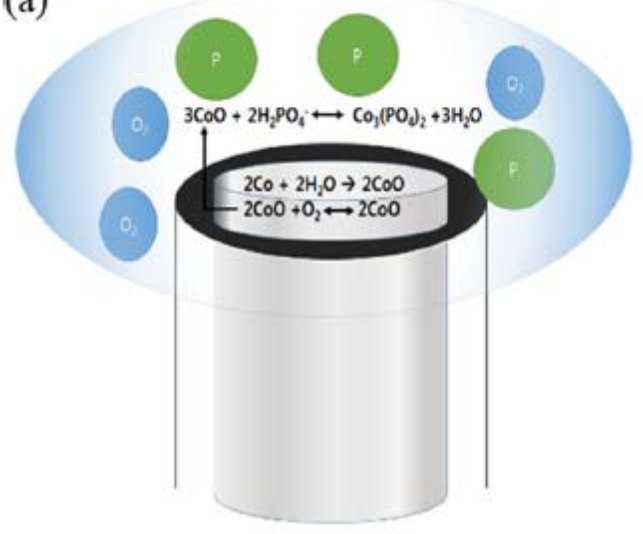

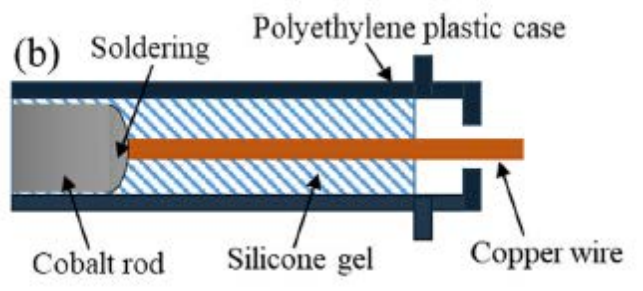

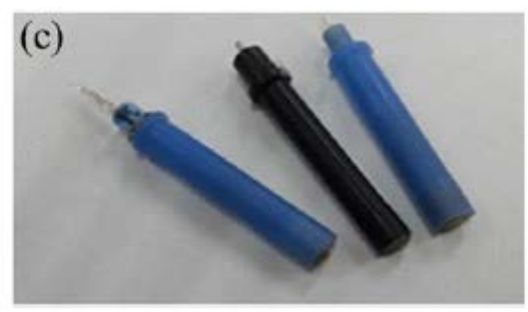

Gambar 3. Mekanisme respon untuk mendeksi $\mathrm{PO}_{4}$ menggunakan elektroda kobalt (a), Komponen elektroda kobalt (b) ISE $\mathrm{PO}_{4}$ berbasis kobalt (Jung et al 2019)

Prinsip kerja sensor ISE PO4 dapat diterangkan sebagai berikut : sebuah elektroda cobalt bereaksi dengan air pada sebuah larutan dan pada permukaannya terjadi reaksi oksidasi sehingga terbentuk sebuah lapisan CoO. Mekanisme reaksi pertukaran ion menyebabkan ikatan yang mengandung hidrogen-hidrogen mencapai kesetimbangan kimia. Medan elektromagnetik elektroda kobalt yang dihasilkan dibandingkan terhadap elektroda referensi dan hasilnya disimpan pada data logger. Selanjutnya dilakukan kalibrasi menggunakan larutan PO4 pada konsentrasi yang berbeda mulai dari larutan yang encer hingga larutan yang pekat.

\section{Tingkat Akurasi Sensor Ion Selective Electrodes (ISE)}

Tingkat akurasi penggunaan sensor ISE memiliki hasil yang tinggi bila dibandingkan dengan pengukuran standar yang dilakukan di laboratorium. Hasil penelitian yang dilakukan oleh Jung et al (2019) bahwa penggunaan ISE $\mathrm{NO}_{3}, \mathrm{Ca}, \mathrm{PO}_{4}$ dan $\mathrm{Mg}$ dalam mengontrol kebutuhan larutan nutrisi dalam budidaya hidroponik tanaman lettuce menunjukan korelasi yang tinggi $\left(\mathrm{R}^{2} 0,96\right)$ antara kadar ion yang diukur menggunakan ISE dengan pengukuran standar yang dilakukan di laboratorium Gambar 4a dan 4b.

Sementara itu konsentrasi aktual pengontrolan menggunakan ISE jika dibandingkan dengan target pengontrolan yang diinginkan juga memiliki korelasi yang sangat tinggi $\left(\mathrm{R}^{2}\right.$ 0,97-0,99) Gambar 4 (c, d, e, f). Hal ini menunjukkan bahwa hasil pengontrolan menggunakan ISE memiliki akurasi yang tinggi sehingga menghasilkan tingkat pengontrolan yang akurat terhadap ion-ion di dalam larutan nutrisi. Hal ini juga dapat dilihat pada Gambar 5(a) dimana konsentrasi ion dalam larutan selalu berada pada nilai target yang telah disetting. Pada gambar 5(c) dapat dilihat bahwa jumlah ion yang di tambahkan sangat bervariasi tergantung dari jumlah pengurangan jumlah ion di 
dalam larutan akibat diserap tanaman dengan nilai setting ion yang dibutuhkan oleh tanaman.

Sementara itu nilai konduktifitas listrik (EC) larutan nutrisi yang dikontrol menggunakan sensor ISE selama pertumbuhan tanaman lettuce menunjukkan nilai yang relatif konstan (Gambar 6). Hal ini menunjukan bahwa pengontrolan nutrisi dalam bentuk ion menggunakan sensor ISE dapat memberikan ion sesuai dengan kebutuhan tanaman, sehingga dapat mengatasi ketidakseimbangan ion di dalam larutan nutrisi yang selama ini terjadi bila pengukuran dilakukan atas kontrol EC.
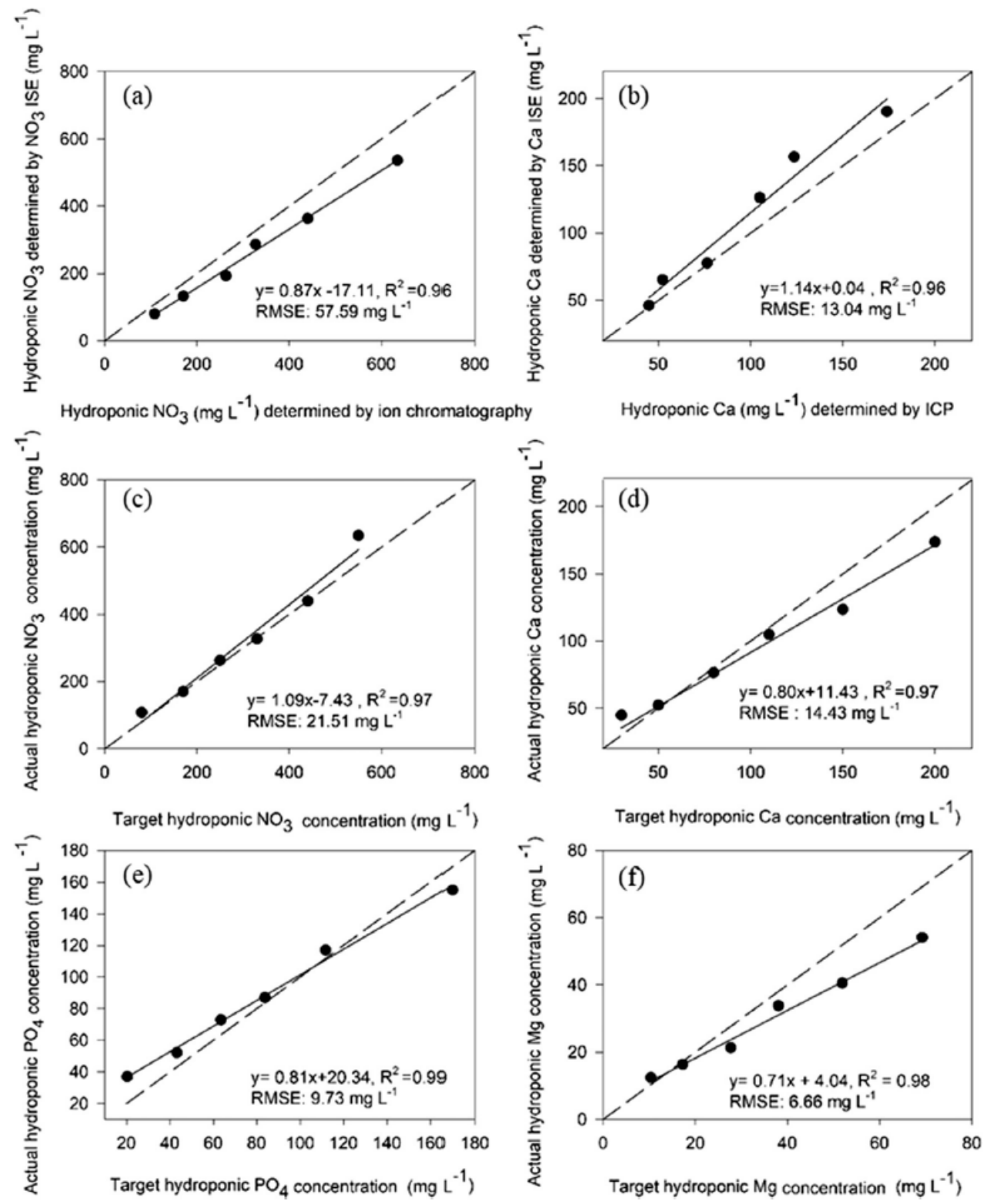

Gambar 4. Hubungan antara kadar ion yang diukur menngunakan ISE dengan pengukuran standar (a dan b), hubungan antara target konsentrasi dengan nilai aktual yang dikontrol oleh sistem kontrol nutrisi (c, d, e, f) (Jung et al 2019) 


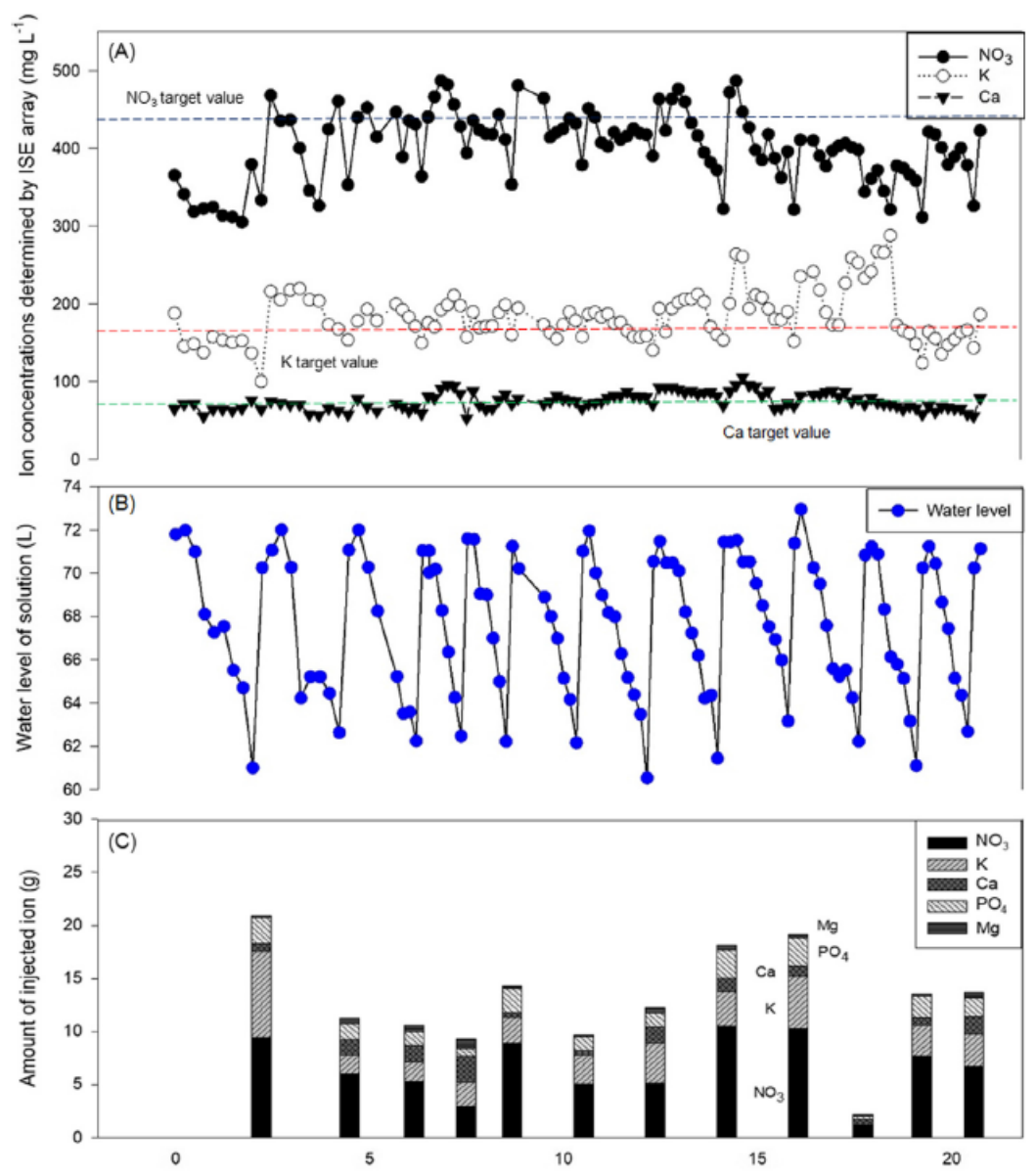

Gambar 5. Perubahan konsentrasi ion yang diukur menggunakan ISE (a), volume air

(b), jumlah ion yang ditambahkan ke dalam larutan nutrisi (c) (Jung et al 2019)

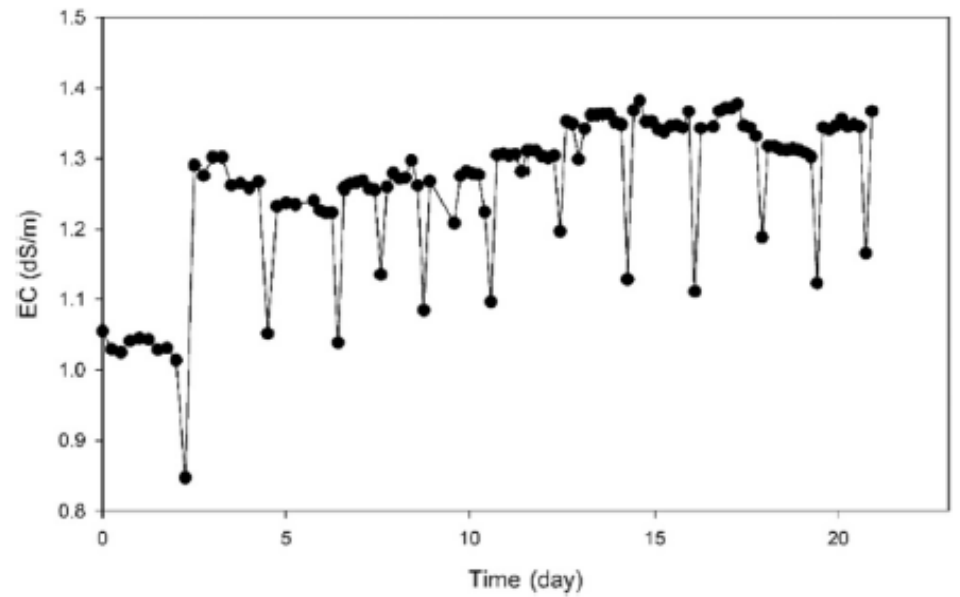

Gambar 6. Perubahan nilai EC total yang diukur selama pertumbuhan tanaman (Jung et al 2019)

Penelitian lain yang dilakukan oleh Cho et al (2018) juga menyatakan bahwa tingkat akurasi dari pengukuran ion $\left(\mathrm{NO}_{3}^{-}\right),\left(\mathrm{K}^{+}\right)$, dan $\left(\mathrm{Ca}^{2+}\right)$ menggunakan ISE pada sistem kontrol hidoponik pada tanaman paprika memiliki akurasi yang cukup tinggi. 
Dari Gambar 7 menunjukkan bahwa tingkat akurasi pengukuran konsentrasi ion menggunakan ISE menunjukan nilai yang tinggi. Hal ini dapat dilihat dari nilai $\mathrm{R}^{2}$ berkisar antara 0,97-0,99.
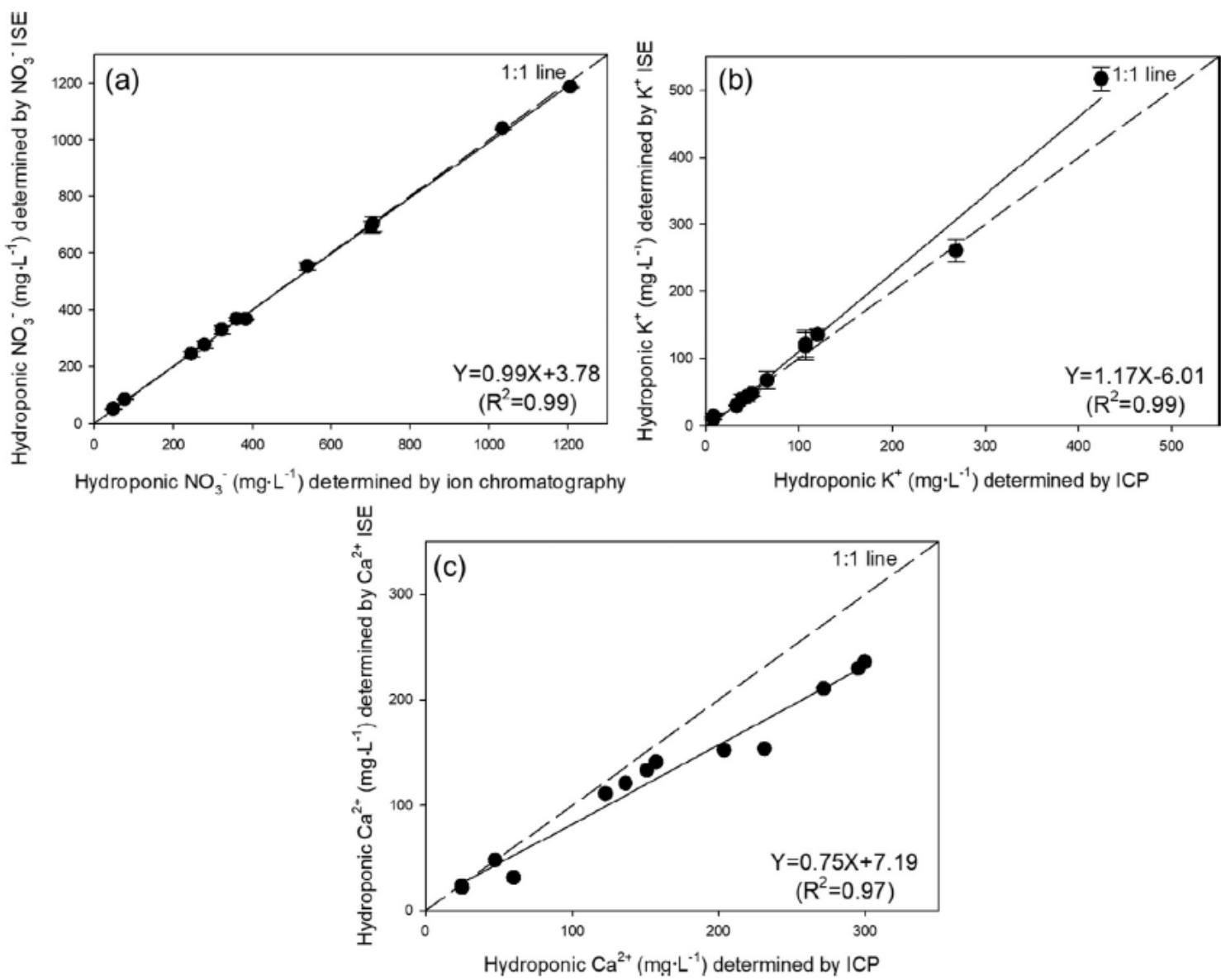

Gambar 7. Hubungan anatara konsentrasi ion yang diukur dengan ISE dengan metode standar pada sistem kontrol hidroponik tanaman paprika (Cho et al 2018)

Dengan nilai akurasi pengukuran konsentrasi ion yang tinggi maka sistem pengontrolan konsentrasi ion dalam larutan nutrisi pada sistem hidroponik juga semakin baik. Hal ini dapat dilihat pada Gambar 8, dimana nilai konsentrasi ion dalam larutan cenderung konstan dan berada pada nilai setting kebutuhan ion tanaman.

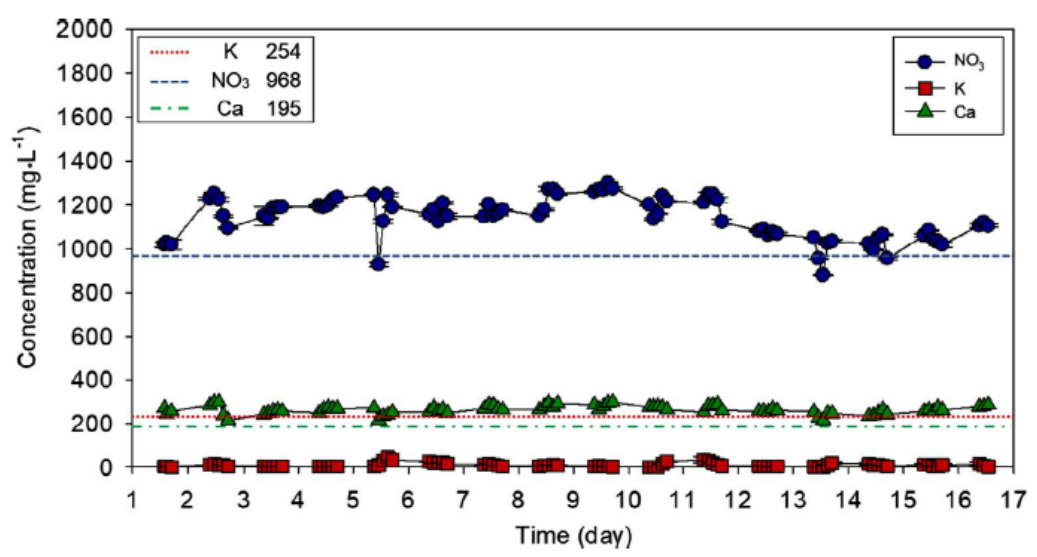

Gambar 8. Perubahan nilai konsetrasi ion di dalam larutan nutrisi hidroponik yang terkontrol pada tanaman paprika (Cho et al 2018) 


\section{Pengembangan Sensor Array Ion Selective Electrodes (ISE)}

Penggunaan gabungan beberapa sensor ISE tunggal memiliki beberapa kelemahan diantaranya adalah biaya operasional yang tinggi karena setiap sensor ISE memiliki elektroda refrensi sendiri-sendiri dan membutukan kalibrasi yang terpisah antar ISE. Untuk mengatasi hal ini Kim et al (2017 ) membuat sensor array ISE yaitu suatu probe yang terdiri dari susunan beberapa ISE yang berbiaya rendah dan terhubung dengan sebuah electroda referensi dengan metode kalibrasi yang sederhana dan mudah digunakan, yang dapat meningkatkan kemampuan pengukuran konsentrasi ion. Bila sensor array ISE dikombinasikan dengan penggunaan mikrokompuer/mikrokontroler maka alat ini dapat digunakan secara portable. Desain array ISE dengan lima sensor ion dan satu elektroda referensi dapat dilihat pada Gambar 9.

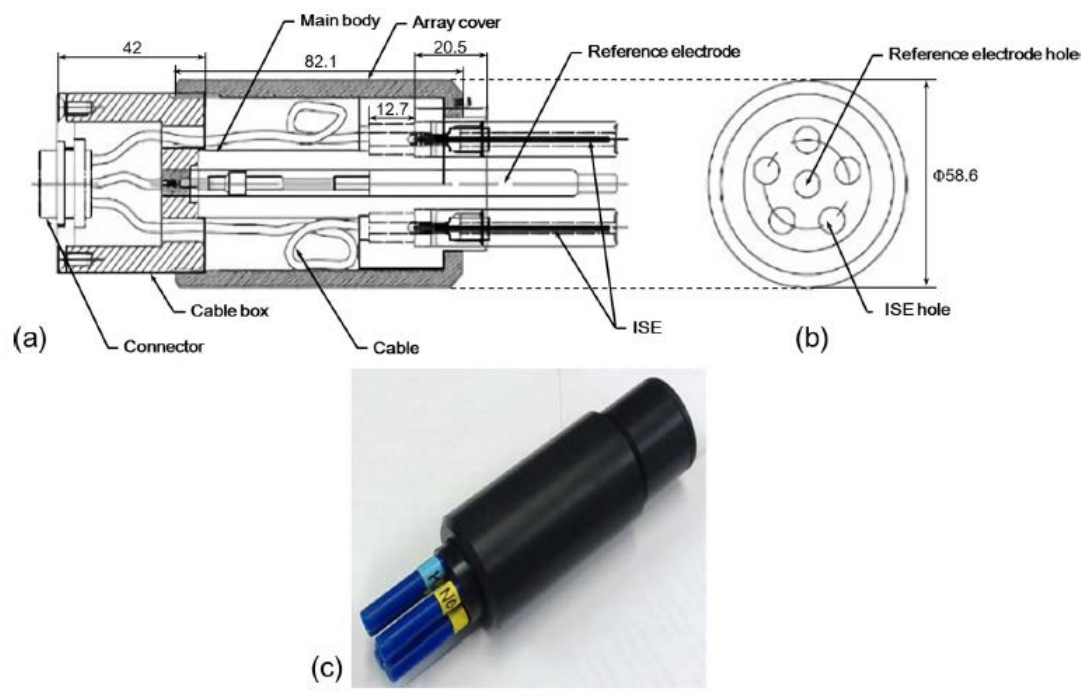

Gambar 9. Desain array ISE dengan 4 elektroda ISE (Kim et al 2017)

Dari hasil pengujian yang dilakukan oleh Kim et al (2017) diperoleh nilai akurasi yang tinggi antara pengukuran menggunakan array ISE dengan metode pengukuran standar. Hal ini dapat dilihat pada Gambar 10 dimana nilai $\mathrm{R}^{2}$ berkisar antara 0,97-0,98.
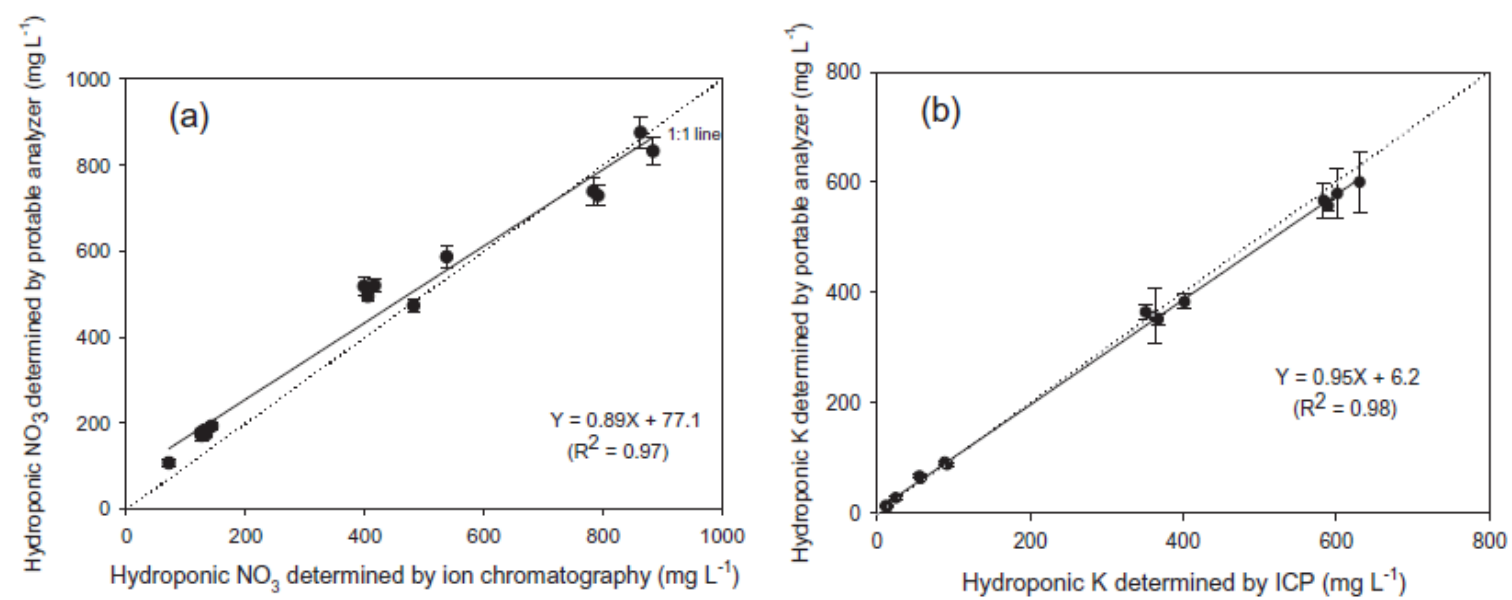

Gambar 10. Hubungan antara pengukuran ion menggunakan array ISE dengan pengukuran standar (Kim et al 2017) 


\section{KESIMPULAN}

Penerapan sensor ISE memberikan nilai akurasi yang tinggi terhadap pengukuran konsentrasi ion di dalam larutan nutrisi, sehingga bila dipadukan dengan mekanisme sistem kontrol menggunakan computer/mikrokontroller yang dapat mengontrol penambahan jumlah ion kedalam larutan nutrisi pada sistem hodroponik secara tertutup sesuai kebutuhan tanaman, maka kesetimbangan jumlah ion pada larutan nutrisi akan tetap terjaga pada level kebutuhan tanaman sehingga tanaman dapat tumbuh dengan baik dan menghasilkan produktivitas optimum. Efisiensi penggunaan unsur hara juga meningkat dan dapat mengurangi pencemaran lingkungan karena sisa drainase nutrisi dapat digunakan lagi.

\section{DAFTAR PUSTAKA}

Cho, W.J., Kim, H.J., Jung, D.H., Kim, D. W., Ahn, T. I., \& Son, J. E. 2018. On-site ion monitoring system for precision hydroponic nutrient management. Computers and Electronics in Agriculture. 146: 51-58.

Jung, D. H., Kim, H. J., Cho, W. J., Park, S. H., \& Yang, S. H. 2019. Validation testing of an ion-specific sensing and control system for precision hydroponic macronutrient management. Computers and Electronics in Agriculture. 156: 660668.

Kim, H. J., Kim D. W., Kim, W. K., Cho, W. J., \& Kang, C. I. 2017. PVC membranebased portable ion analyzer for hydroponic and water monitoring. Computers and Electronics in Agriculture. 140: 374-385.

Kim, H. J., Kim, W. K., Roh, M. Y., Kang, C. I., Park, J. M. \& Sudduth, K. A. 2013. Automated sensing of hydroponic macronutrients using a computer-controlled system with an array of ion-selective electrodes, Computers and Electronics in Agriculture, Volume 93:46-54.

Ruiz, F. XR., Andrade, F. J., Riu, J., \& Rius, F. X. 2014. Computer-operated analytical platform for the determination of nutrients in hydroponic systems. Food Chemistry. 147: 92-97. 